\section{References}

1 Artz T D, Levine D B, Lim W N, Salvati E A, Wilson P D. Neonatal diagnosis, treatment, and related factors of congenital dislocation of the hip. Clin Orthop 1975; 110: 112-36.

2 Cyvin K B. Congenital dislocation of the hip joint. Clinical studies with special reference to the pathogenesis. Acta Paediatr Scand [Suppl] 1977; 263: 1-67.

3 Hensinger $R \mathbf{N}$. Congenital dislocation of the hip. Clinical Symposia, 31 January 1979, Ciba.

4 Dunn P M. Perinatal observations on the etiology of congenital dislocation of the hip. Clin Orthop 1976; 119: 11-22.

5 Clarke M F. Stature and hip width of young Indian women students of medicine and nursing. Hum Biol 1971; 43: $549-56$
6 Endo M, Iinuma TA, Umegaki Y, Tateno $Y$, Tanaka $H$, Tsuchiya K. Automated diagnosis of congenital dis location of the hip. Radiology 1977; 122: 25-30.

7 Heath B H, Hopkins C E, Miller C D. Physiques of Hawaii-born young men and women of Japanese ancestry, compared with college men and women of the United States and England. Am J Phys Anthropol 1961; 19: 173-84.

8 Dunn P M. Congenital deformation following premature rupture of the membranes (abstract). Teratology 1971; 4: 487.

Correspondence to Dr I Amitai, Paediatric Department, Hadassah University Hospital, Mount Scopus, POB 24035, Jerusalem 91240, Israel.

Received 19 May 1982

\title{
Congenital isolated thyrotrophin releasing hormone deficiency
}

\author{
H NIIMI, H INOMATA, N SASAKI, AND H NAKAJIMA \\ Department of Paediatrics, School of Medicine, Chiba University, Chiba, Japan
}

SUMMARY A $4 \frac{1}{3}$-year-old girl with congenital thyrotrophin-releasing hormone (TRH) deficiency is described. Oral TRH administration led to normal thyroid hormone and TRH levels in the blood; favourable growth and development was achieved.

Deficiency of thyroid-stimulating hormone (TSH) and hypothyroidism can occur in any condition that is associated with developmental defects of the pituitary or hypothalamus, or in children with idiopathic hypopituitarism. However isolated deficiency of TSH, or thyrotrophin-releasing hormone (TRH) is rare. ${ }^{12}$ We describe in detail a case of isolated TRH deficiency.

\section{Case report}

A $4 \frac{1}{3}$ year-old girl was referred to us because she was short.

She was the third child of healthy, intelligent parents. Pregnancy and delivery had been normal, as had been the neonatal period. Birthweight was $3200 \mathrm{~g}$ and length $50 \mathrm{~cm}$. Growth to age 1 year had apparently been normal but retardation of growth was noticed at 2-3 years of age.

Her parents were not related, but her maternal grandparents were consanguineous. There was no family history of thyroid disease, dwarfism, or mental abnormality.

Physical examinations showed height $93.0 \mathrm{~cm}$ $(-2.0 \mathrm{SD}$ of the mean height for Japanese girls as reported by the Japanese Ministry of Health and Welfare), weight $13.0 \mathrm{~kg}(-1.6 \mathrm{SD})$, with normal body proportions. The thyroid gland was not enlarged, and the remainder of the physical examina- tion was normal. Roentgenograms of the skull were normal and bone age was $2 \frac{3}{4}$ years.

Haematological studies, urine analysis, and blood chemical determinations were normal. An electroencephalogram was normal. Computerised tomography scans of the skull were normal. Her developmental quotient was estimated to be 112 .

At the initial visit, the serum thyroxine (T4) value was $4 \cdot 1 \mu \mathrm{g} / 100 \mathrm{ml}(52 \cdot 8 \mathrm{nmol} / \mathrm{l})$ (normal $4 \cdot 5-13 \cdot 5$ $\mu \mathrm{g} / 100 \mathrm{ml}$ ), serum tri-iodothyronine (T3) $177 \mathrm{ng} /$ $100 \mathrm{ml} \quad(2 \cdot 7 \mathrm{nmol} / \mathrm{l})$ (normal $98-202 \mathrm{ng} / 100 \mathrm{ml}$ ), and serum TSH $14 \mu \mathrm{U} / \mathrm{ml}$ (normal $<2-8$ ). Thyroid uptake of ${ }^{123}$ I sodium iodide was $7 \cdot 1 \%$ at 24 hours (normal 10-40\%). A thyroid scan gave normal results. Tests for antithyroglobulin antibody and antimicrosome antibody were negative. The serum thyroxine binding globulin determined by radioimmunoassay was $20 \cdot 3 \mu \mathrm{g} / \mathrm{ml}(338 \cdot 3 \mathrm{nmol} / \mathrm{l}$ ) (normal $15 \cdot 7-43 \cdot 3 \mu \mathrm{g} / \mathrm{ml})$.

A peak TSH level of $70 \mu \mathrm{U} / \mathrm{ml}$ was obtained after administration of $130 \mu \mathrm{g}(10 \mu \mathrm{g} / \mathrm{kg})$ of $\mathrm{TRH}$ intravenously (normal $10-40 \mu \mathrm{U} / \mathrm{ml}$ ). Two additional TRH tests showed similar positive responses. Luteinising hormone and follicle-stimulating hormone showed normal responses to intravenous injection of $40 \mu \mathrm{g}$ of luteinising hormone-releasing hormone. Serum growth hormone was demonstrable in the fasting state $(3 \cdot 2 \mathrm{ng} / \mathrm{ml})$, and an increase was obtained during insulin-induced hypoglycaemia $(20.5 \mathrm{ng} / \mathrm{ml})$. The plasma level of adrenocorticotrophin was $16 \mathrm{pg} / \mathrm{ml}$ (normal 15-85) in the early morning and a peak level of $27 \mathrm{pg} / \mathrm{ml}$ was obtained by insulin-induced hypoglycaemia. Urinary 17-OHCS were $3.9 \mathrm{mg}$ and urinary 17-ketosteroids $0.1 \mathrm{mg} / 24$ hours. Serum prolactin level was 16.4 
$\mathrm{ng} / \mathrm{ml}$ and a peak level of $101.7 \mathrm{ng} / \mathrm{ml}$ was obtained by TRH administration.

The concentration of serum TRH determined by radioimmunoassay ${ }^{3}$ was below the limit of detectability $(<2 \mathrm{pg} / \mathrm{ml})$. Methimazole $(20 \mathrm{mg})$ was given for 10 days but the serum TRH still remained below $2 \mathrm{pg} / \mathrm{ml}$ without any increase in secretion. When $30 \mathrm{mg}$ methimazole was given for 10 days to an adult in a TRH secretion stimulation test a peak level of $>20 \mathrm{pg} / \mathrm{ml}$ was reached (T Mitsuma, 1979, personal communication). ${ }^{4}$

\section{Discussion}

Now that radioimmunoassay of pituitary hormones is possible, diagnosis of isolated deficiency of each of the pituitary hormones is based on firmer grounds than previously. Such developments have led to considerably more patients being diagnosed with hypothyroidism due to TRH deficiency among hypothyroid patients with pituitary dwarfism or organic disturbance of the hypothalamus. However, only a few cases of idiopathic isolated TRH deficiency have been reported, one probably due to congenital cause $e^{4}$ and two probably acquired postnatally. ${ }^{56}$ This case may be the first of isolated TRH deficiency confirmed by radioimmunoassay measurement of TRH to be reported.

A child with short stature and normal proportions, delayed bone age, no anaemia, and normal developmental quotient made us at first suspect pituitary dwarfism. Insulin loading however, successfully stimulated growth hormone secretion.

Levels of serum TSH were initially a little raised at $14 \mu \mathrm{U} / \mathrm{ml}$. T4 was low at $4 \cdot 1 \mu \mathrm{g} / 100 \mathrm{ml}$ with excessive response to TRH. Thyroidal ${ }^{123}$ I uptake was $7 \cdot 1 \%$ after 24 hours, which suggested hypothyroidism.

Antithyroid antibodies were negative and the thyroid gland was not enlarged. A thyroid scan gave normal results. Since serum T3 level increased on TRH administration, as reported from some investigators, hypothyroidism in this patient was thought to be neither primary nor to be mediated by the pituitary.

A long-term follow-up without medication showed fluctuations of serum T4 between the lower limit of normal and low normal levels. If levels of serum T4 declined, levels of serum TSH increased with excessive response to TRH. A similar case in which isolated TRH deficiency was diagnosed in an adult patient in whom serum TSH was occasionally a little increased has been reported. ${ }^{5}$ The negative feedback mechanism in the pituitary-thyroid axis of these patients was probably maintained at normal. Pituitary hormones other than TSH increased to respective secretory stimuli: growth hormone, adrenocorticotrophin, and cortisol to insulin, $\mathrm{LH}$ and FSH to luteinising hormone-releasing hormone, prolactin to TRH, with a slight delay in some of them.

TRH in the serum measured by radioimmunoassay, was below the limit of detection, and the level did not increase in a TRH secretion stimulation test.

This patient had no history of trauma nor did she have neurological abnormalities. Computerised tomography scans of the skull and electroencephalogram obtained in order to detect a possible organic lesion showed no abnormalities.

According to these findings, congenital isolated TRH deficiency probably caused hypothyroidism in this patient. TRH was therefore administered orally. Optimal dose of TRH appeared to be 4-6 $\mathrm{mg} /$ day orally. Serum TRH level was maintained within normal limits, $8-10 \mathrm{pg} / \mathrm{ml}$ (normal $<2-60$ ) and growth and development also proceeded normally. The body height, which had been $-2 \cdot 0$ SD before treatment, became $-1.0 \mathrm{SD}$ after oral administration of TRH for 2 years and 8 months. Bone age also corresponds to chronological age at present.

In the hypothalamus, there is an enzyme for synthesising TRH according to some reports. ${ }^{7}$ In congenital TRH deficiency, this TRH synthesising enzyme is probably deficient.

We thank Dr T Mitsuma, Aichi Medical College, for providing the TRH determinations.

\section{References}

1 Miyai K, Azukizawa M, Kumahara Y. Familial isolated thyrotropin deficiency with cretinism. N Engl J Med 1971; 285: 1043-8.

2 Dussault J H, Letarte J, Guyda H, Laberge C. Thyroid function in neonatal hypothyroidism. J Pediatr 1976; 89: $541-4$

3 Mitsuma T, Hirooka Y, Nihei N. Radioimmunoassay of thyrotropin releasing hormone in human serum and its clinical application. Acta Endocrinol 1976; 83: 225-35.

4 Oomura J, Kato K, Harayama N, Shimizu S, Iwagaki H. A case of TRH deficiency (probably isolated) (abstract). Acta Pediatr Jpn 1974; 78 : 174-5.

5 Yoshimoto S, Moridera K, Miyamoto Y, Imamura R, Fukunaga $\mathbf{H}$, Imura $\mathbf{H}$. Isolated thyrotrophin releasing hormone deficiency (Japanese). Nippon Rinsho 1974; 32: 2405-10.

6 Katagami $\mathrm{H}$, Kato $\mathrm{Y}$, Ishida $\mathrm{H}$, et al. A case of isolated TRH deficiency (abstract). Nippon Naibunpi Gakkai Zasshi 1980; 56: 1256.

7 Mitnick M, Reichlin S. Enzymatic synthesis of thyrotropin-releasing hormone (TRH) by hypothalamic 'TRH synthetase'. Endocrinology 1972; 91: 1145-53.

Correspondence to Dr $\mathbf{H}$ Niimi, Department of Paediatrics, School of Medicine, Chiba University, Inohanacho, Chiba 280, Japan.

Received 20 April 1982 